\title{
Phytochemical profiling, and anti-oxidant, anti-bacterial, and anti-inflammatory properties of Viburnum coriaceum Blume
}

\author{
Vijayakumar Vijaytha' ${ }^{1}$ R. V. Anupama ${ }^{1}$ and M. Haridas ${ }^{2 *}$
}

\begin{abstract}
Background: Viburnums comprise a taxonomic group of plants distributed all over the world and were reported to have many biological activities. Viburnum coriaceum Blume is one of the least explored members of the group. The present study was aimed to explore the phytochemical profile of the plant, Viburnum coriaceum Blume with special emphasis to its anti-oxidant, anti-bacterial, and anti-inflammatory activities.

Results: Extracts of all parts of plants were found to possess a spectrum of chemicals in considerable amount, including triterpenoids and glycosides. Anti-oxidant property was found in extracts made of any part of the plant. Methanol extract of root expressed a prominent zone of inhibition in agar gel well-diffusion assay involving many microorganisms. Inhibition of enzymes, LOX, and trypsin showed by the hexane extract of root suggested a prominent anti-inflammatory potential of the plant under investigation.

Conclusion: Phytochemical profiling and the other assays using the plant extracts provide us with a plant having many valuable medicinal properties. Viburnum coriaceum Blume could be noted as a promising material for drug leads.
\end{abstract}

Keywords: Viburnum coriaceum, Phytochemicals, Anti-oxidant, Anti-bacterial, Anti-inflammatory

\section{Background}

Genus Viburnum is a group of around 200 shrubs and small trees, under the Adoxaceae family [1]. They are primarily distributed in the temperate climatic zone of Northern Hemisphere and in the tropical mountains of Australia and Tasmania. Great diversity among these plants are seen in the Himalayan regions and China [2]. Health benefits of Viburnums were known from earlier times. Cramp bark (Viburnum opulus) and black haw (Viburnum prunifolium) have a long history in the medications associated with pregnancy, especially during miscarriages among the native American tribes [3]. They are also found to be effective in muscle cramps, back pain, pain in thighs, etc. and animal/clinical studies

\footnotetext{
* Correspondence: mharidasm@rediffmail.com

${ }^{2}$ Inter University Centre for Biosciences, Kannur University, Thalassery 670661, Kerala, India

Full list of author information is available at the end of the article
}

proved their relaxing effects on muscles, especially uterus and thighs [4]. V. opulus is used in homeopathic medicine for the treatment of dysmenorrhea and have other health benefits too [5, 6]. Viburnum lantana [7], Viburnum macrocephalum [8], Viburnum grandiflorum [9], Viburnum dilatatum [10], etc. are some other important species with reported medicinal properties. Antioxidant $[7,10]$, anti-microbial $[8,9,11]$, anti-diabetic [10], anti-inflammatory [12, 13], anti-nociceptive [12], and hepato-protective [14] effects were also reported from these species. A number of bioactive compounds have been isolated from different Viburnums including monoterpenes, iridoids and iridoid glycosides $[15,16]$.

Viburnum coriaceum Blume, synonym Viburnum cylindricum Buch-Ham. Ex D. Don has not been described as in detail as the other members of its genera. It is an evergreen large shrub growing up to $7 \mathrm{~m}$ long, seen in altitude of $1000-2500 \mathrm{~m}$. It has been described in

\section{Springer Open}

( ) The Author(s). 2020 Open Access This article is licensed under a Creative Commons Attribution 4.0 International License, which permits use, sharing, adaptation, distribution and reproduction in any medium or format, as long as you give appropriate credit to the original author(s) and the source, provide a link to the Creative Commons licence, and indicate if changes were made. The images or other third party material in this article are included in the article's Creative Commons licence, unless indicated otherwise in a credit line to the material. If material is not included in the article's Creative Commons licence and your intended use is not permitted by statutory regulation or exceeds the permitted use, you will need to obtain permission directly from the copyright holder. To view a copy of this licence, visit http://creativecommons.org/licenses/by/4.0/. 
Ayurveda [17]. V. coriaceum is phylogenetically related to $V$. opulus, a plant with high medicinal values [18]. Formulations from $V$. coriaceum were reported with anti-convulsant property, and thus became important for its applicability in medicinal field [19]. It befits further investigation with a detailed check on its phytochemical profile. Hence, focus of the present study is to explore the rich phyto-constituents of the plant and its medicinal properties with special emphasis on antioxidant, anti-bacterial, and anti-inflammatory activities. With the increase in the challenge of staying healthy, need for new medicines/nutraceuticals will never end.

\section{Methods}

\section{Plant material: collection and identification}

Plant materials were collected from the Nilgiri Hills of Tamil Nadu, India during the month of August, and dried under shade and powdered. Roots and aerial parts were powdered separately. The material was identified and authenticated by Dr. Prabhukumar K. M., Scientist and Head, Plant Systematics and Genetics Division, Centre for Medicinal Plants Research (CMPR), Kottakkal, India and the voucher specimen (CMPR 8670) was deposited at CMPR Raw Drug Museum.

\section{Extraction}

Roots and aerial parts were extracted with hexane, methanol, and water successively. All the extracts were concentrated and stored for further studies [20].

\section{Qualitative phytochemical analysis Test for alkaloids}

Two tests were performed to confirm the presence of alkaloids in the samples. In the first test, (Hager's) 2 $\mathrm{mL}$ of plant extract was mixed with $2 \mathrm{~mL}$ of Hager's reagent (saturated aqueous solution of picric acid). An eye catching yellow precipitate pointed to a positive result [21].

In Wagner's test for alkaloids, $2 \mathrm{~mL}$ of Wagner's reagent $(2 \mathrm{~g}$ of iodine and $6 \mathrm{~g}$ of potassium iodide in $100 \mathrm{~mL}$ distilled water) was added to $2 \mathrm{~mL}$ of plant extract. Reddish brown precipitate indicated positive result [22].

\section{Test for flavonoids}

Alkaline reagent test was used for the detection of flavonoids. To $2 \mathrm{~mL}$ of the test sample, a few drops of sodium hydroxide solution were added. An intense yellow color was developed and which faded on addition of dilute hydrochloric acid [21, 23].

\section{Test for tannins}

Presence of tannins in the extract was detected by treating $1 \mathrm{~mL}$ of plant extract with a few drops of $1 \%$ gelatin in $10 \%$ sodium chloride solution. Formation of a white precipitate indicates positive result [21].

\section{Test for triterpenoids}

Two milliliters of plant extract was mixed with $1 \mathrm{~mL}$ of chloroform and a few drops of concentrated sulfuric acid were added along the sides of the test tube. A reddish brown color at the interphase shows the presence of triterpenoids [22].

\section{Test for glycosides}

Acid hydrolysis of the plant extracts were done initially. To $2 \mathrm{~mL}$ of the hydrolysate, $3 \mathrm{~mL}$ chloroform was added and shaken well, kept undisturbed for the formation of two separate layers. To the chloroform layer, equal volume of $10 \%$ ammonia solution was added. Pinkish red color indicated the presence of anthraquinone glycosides (Borntrager's test) [21, 22].

In the second test, $2 \mathrm{~mL}$ of plant extract was treated with $1 \mathrm{~mL}$ glacial acetic acid. A few drops of 5\% ferric chloride and concentrated sulfuric acid were added by the sides of the test tube. Appearance of a reddish brown ring at the junction of two liquids indicated the presence of cardiac glycosides [21, 23].

\section{Test for saponins}

Foam test was used to detect the presence of saponins. Then, $2 \mathrm{~mL}$ of the extracts was mixed with $10 \mathrm{~mL}$ of distilled water and mixed vigorously. Observation of persistent foam indicated the positive result $[22,23]$.

\section{Test for anthocyanins}

One milliliter of plant extract and $1 \mathrm{~mL}$ of $2 \mathrm{~N}$ sodium hydroxide solution were heated in water bath for $5 \mathrm{~min}$ at $100{ }^{\circ} \mathrm{C}$. Formation of a bluish green color indicated the presence of anthocyanins [24].

\section{Quantitative phytochemical analysis Alkaloids}

Alkaloids in a plant sample were quantitatively measured by Harborne methodology [20, 21]. Then, $2.5 \mathrm{~g}$ of plant sample taken in a $250 \mathrm{~mL}$ beaker was treated with $200 \mathrm{~mL}$ of $10 \%$ glacial acetic acid in ethanol and allowed to stand for $4 \mathrm{~h}$ for extraction. The extract was then concentrated in a water bath till it got reduced to 1/4th. Concentrated ammonium hydroxide solution was added drop wise till complete precipitation occurred. After $3 \mathrm{~h}$ of standing for sedimentation, the supernatant was discarded and the precipitate was washed with dilute ammonium hydroxide and then filtered. The residue was dried in 
an oven and weighed. Percentage of alkaloid content in a given amount of the sample was calculated by

$$
\% \text { of Alkaloid }=\left(\frac{\text { Weight of alkaloid }}{\text { Weight of sample }}\right) \times 100
$$

\section{Flavonoids \\ Total flavonoid content of the sample was determined by aluminium chloride calorimetric method $[25,26]$. In this reaction, aluminium chloride would form acid stable complexes with C-4 keto group and either C-3 or C-5 hydroxyl group of flavones and flavonols. Also, alumin- ium chloride formed acid labile complexes with ortho dihydroxyl groups in the A and B rings of flavonoids. Different concentrations of quercetin were used to gen- erate calibration curve. Different concentrations of quer- cetin and the samples to be tested were prepared in methanol. Then, $0.5 \mathrm{~mL}$ of the test solutions and the standard solutions were mixed with $1.5 \mathrm{~mL}$ of methanol, $0.1 \mathrm{~mL}$ of $10 \%$ aluminium chloride, $0.1 \mathrm{~mL}$ of $1 \mathrm{M}$ po- tassium acetate, and $2.8 \mathrm{~mL}$ of distilled water. For blank, $10 \%$ aluminium chloride was replaced by equal amount of distilled water. After 30-min incubation at room temperature, absorbance was measured at $415 \mathrm{~nm}$ in UV/visible spectrophotometer (Thermo Scientific Evolu- tion 201). The results were obtained as microgram quer- cetin equivalent per milliliter of the sample.}

\section{Tannins}

Tannin content was measured by a modified FolinCiocalteu method [27, 28]. Then, $0.5 \mathrm{~mL}$ of the sample was mixed with $3.75 \mathrm{~mL}$ of distilled water. To this mixture, $0.25 \mathrm{~mL}$ of Folin-Ciocalteu reagent and $0.5 \mathrm{~mL}$ of $35 \%$ sodium carbonate solution were added and incubated at room temperature for $30 \mathrm{~min}$. Then, absorbance was measured at $725 \mathrm{~nm}$. Total tannin content was expressed as tannic acid equivalents in $\mu \mathrm{g} / \mathrm{mL}$ of plant extract.

\section{Phenols}

Total polyphenols in a sample was determined by spectrophotometric method [28, 29]. Polyphenols formed a blue complex with some specific redox reagents that could be quantified spectrophotometrically. This blue complex is phosphotungstic acid-phosphomolybdenum complex and its maximum absorption depends on the alkaline solution and the concentration of phenolic compounds [30]. One milliliter of the sample extract was added to tubes containing $5 \mathrm{~mL}$ of 1:10 dilution of Folin-Ciocalteu reagent in water and $4 \mathrm{~mL}$ of $7.5 \%$ sodium carbonate solution. The tubes were then incubated for $1 \mathrm{~h}$ at room temperature. The absorbance was finally measured at 765 nm. Total phenol content was expressed as gallic acid equivalents in $\mu \mathrm{g} / \mathrm{mL}$ of plant extract.

\section{In vitro anti-oxidant assays}

\section{DPPH radical scavenging assay}

A stable free radical 1,1-diphenyl-2-picrylhydrazyl (DPPH), having a free electron, showed high absorbance at $517 \mathrm{~nm}$. DPPH solution has a characteristic deep purple color which gets faded and converted to golden yellow upon accepting hydrogen from corresponding donors. This discoloration was proportional to the concentration and the scavenging activity of the compounds present in the plant extracts. Then, $2.8 \mathrm{~mL}$ of $100 \mu \mathrm{M}$ $\mathrm{DPPH}$ in methanol was mixed with different concentrations $(12.5,25,37.5$, and $50 \mathrm{mg} / \mathrm{mL})$ of plant extracts in $0.2 \mathrm{~mL}$ of methanol. Dosages for all the assays were planned according to the inhibition shown by the extracts at minimum concentration. The mixture was then incubated at room temperature for $30 \mathrm{~min}$. Absorbance was measured at $517 \mathrm{~nm}$ after shaking well. DPPH and methanol solution without the extract served as control and methanol solution alone as blank. Same test was repeated with different concentrations of ascorbic acid to get a standard graph [23, 31].

$$
\begin{aligned}
& \text { Percentage of DPPH scavenging activity } \\
& \quad=\left(\frac{\text { Absorbance of control }- \text { Absorbance of test }}{\text { Absorbance of control }}\right) \times 100
\end{aligned}
$$

\section{$A B T S$ radical scavenging assay}

ABTS (2,2'-azinobis (3-ethylbenzothiazoline)-6-sulfonic acid) radical is generated when a strong oxidizing agent like potassium permanganate or potassium per sulfate reacts with ABTS salt. The ability of the anti-oxidants present in the extract to scavenge ABTS radical generated in the aqueous phase is assayed comparing to a positive standard ascorbic acid. Blue-green color of the ABTS radical solution gets reduced by the hydrogen donated by the anti-oxidants and this can be measured by suppression in the absorption spectrum of wavelength $734 \mathrm{~nm}$ [32]. Equal quantities of 7.4 mM ABTS solution and $2.6 \mathrm{mM}$ potassium per sulfate solution were mixed and incubated at room temperature for $12 \mathrm{~h}$ in dark to prepare the working solution. One milliliter of the working solution was mixed with $60 \mathrm{~mL}$ of methanol and its absorbance was measured at $734 \mathrm{~nm}$. Absorbance value was adjusted to 1.17 by adding methanol or working solution. When the absorbance reached 1.17, absorbance of the samples was measured. Different concentrations $(0.25,0.5,0.75$, and $1 \mathrm{mg} / \mathrm{mL})$ of the extracts were taken as samples. Samples were prepared by mixing $150 \mu \mathrm{L}$ of the extract with $2850 \mu \mathrm{L}$ of the working solution and incubated at $2 \mathrm{~h}$ in dark. Methanol was taken as the blank and working solution in methanol was taken as control. Standard graph was prepared by repeating the experiment with different concentrations of ascorbic acid. 
Percentage of ABTS scavenging activity

$$
=\left(\frac{\text { Absorbance of control }- \text { Absorbance of test }}{\text { Absorbance of control }}\right) \times 100
$$

\section{Hydroxyl radical scavenging assay}

Oxidative stress developed by the reactive oxygen species (ROS) are commonly believed to cause damage to the biomolecules [33, 34]. Hydroxyl radicals are one of the potent ROS developed in the cells. The ability of the anti-oxidant compounds to compete with salicylic acid for scavenging the hydroxyl radicals was assayed. Reaction mixture contained $1 \mathrm{~mL}$ of $1.5 \mathrm{mM}$ ferrous sulfate, $0.7 \mathrm{~mL}$ of $6 \mathrm{mM}$ hydrogen peroxide, $0.3 \mathrm{~mL}$ of $20 \mathrm{mM}$ sodium salicylate, and $1 \mathrm{~mL}$ of various concentrations $(0.25,0.5,0.75$, and $1 \mathrm{mg} / \mathrm{mL})$ of the extracts. The reactants were mixed and incubated at $37{ }^{\circ} \mathrm{C}$ for $1 \mathrm{~h}$ and then the absorbance was measured at $562 \mathrm{~nm}$. The absorbance measured was due to the hydroxylated salicylate complex. Percentage of scavenging was calculated by the equation:

$$
\% \text { of scavenging }=1-\left(\frac{A_{1}-A_{2}}{A_{0}}\right) \times 100
$$

$A_{0}$ is the absorbance of control (reactants without extract), $A_{1}$ is the absorbance of reactants in the presence of extract, and $A_{2}$ is the absorbance of reactants except sodium salicylate in the presence of extracts. Ascorbic acid was the standard used.

\section{In vitro anti-bacterial assay}

Anti-bacterial activity of the roots and aerial parts extracts of the plant was tested with different bacterial strains by agar gel well-diffusion method [35]. Clinical strains of Staphylococcus aureus, Pseudomonas sp., Klebsiella sp., Escherichia coli, and Salmonella typhi were collected from a local clinical lab. Some other strains of the same species were also used for the study. Muller Hinton agar plates were prepared and the wells were cut with a micro tip. The extracts were prepared at a concentration of $1 \mathrm{mg} / \mathrm{mL}$. Further, $100 \mu \mathrm{L}$ extracts (hexane, methanol, and water) in dimethyl sulfoxide (DMSO) were added to the wells and incubated at $37{ }^{\circ} \mathrm{C}$ for $24 \mathrm{~h}$. Then, $100 \mu \mathrm{L}$ of DMSO was used as the blank. Inhibition zones were measured to know the antibacterial potential. The positive samples were further analyzed by applying increasing concentrations of extracts $(0.25,0.50,1.0,2.0 \mathrm{mg} / \mathrm{mL})$.

\section{In vitro anti-inflammatory assays Trypsin inhibition assay}

Continuous-rate spectrophotometric method developed by Sigma Aldrich [36] with slight modifications was used for the assay. The activity of the inhibitor was expressed as the inhibition of active fraction mass units. The substrate used was $0.25 \mathrm{mM} N_{\alpha}$-benzoyl-L-arginine ethyl ester (BAEE) in phosphate buffer at $\mathrm{pH}$ 7.6. One unit of BAEE will show an absorbance of 0.001 per minute at $7.6 \mathrm{pH}$. Enzyme $(0.05 \mathrm{mM})$ was prepared in ice-cold $0.001 \mathrm{M}$ hydrochloric acid and the extract fractions in DMSO. The reaction mixture contains a total volume of $3.4 \mathrm{~mL}$ with $3 \mathrm{~mL}$ substrate, $0.2 \mathrm{~mL}$ enzyme, and $0.2 \mathrm{~mL}$ inhibitor. Enzyme and the inhibitor fractions were incubated for $10 \mathrm{~min}$, then the substrate was added and the readings were taken at $253 \mathrm{~nm}$ by time scanning for 10 min. Phenyl methyl sulfonyl fluoride (PMSF) was used as the standard inhibitor.

Blank $\rightarrow 0.2 \mathrm{~mL}$ DMSO, $0.2 \mathrm{~mL} \mathrm{HCl}$, and $3 \mathrm{~mL}$ substrate

Activity of the native enzyme $(\mathrm{N}) \rightarrow 0.2 \mathrm{~mL}$ DMSO, $0.2 \mathrm{~mL}$ enzyme, and $3 \mathrm{~mL}$ substrate

Activity of enzyme in the presence of inhibitor (I) $\rightarrow$ $0.2 \mathrm{~mL}$ inhibitor, $0.2 \mathrm{~mL}$ enzyme, and $3 \mathrm{~mL}$ substrate

$$
\% \text { of Inhibition }=\left(\frac{N-I}{N}\right) \times 100
$$

\section{Lipoxygenase inhibition assay}

Lipoxygenase (LOX) inhibition assay developed by Arthon and Barrett [26] with slight modifications were applied for activity analysis. LOX (EC 1.13.11.12) type I$\mathrm{B}$ (soya bean) was the enzyme used and linoleic acid was the substrate used. Further, $0.93 \mu \mathrm{M}$ solution of enzyme was prepared in $0.2 \mathrm{mM}$ borate buffer at $\mathrm{pH}$ 8.6. Then, $0.32 \mathrm{mM}$ substrate was also prepared in same buffer at the same $\mathrm{pH}$. The assay mixture contains $50 \mu \mathrm{L}$ enzyme, $360 \mu \mathrm{L}$ substrate, and $1.59 \mathrm{~mL}$ borate buffer making the final volume of $2 \mathrm{~mL}$. While adding inhibitor to the reaction mixture, $50 \mu \mathrm{L}$ of inhibitor was added and the buffer volume was reduced to $1.54 \mathrm{~mL}$ to maintain the total volume at $2 \mathrm{~mL}$. Formation of hydroperoxyoctadecadienoic acid was the indicator of LOX activity, which could be measured in a spectrophotometer at 234 $\mathrm{nm}$. Vanillin was used as the standard inhibitor. The blank solution contained $50 \mu \mathrm{L}$ DMSO, $1590 \mu \mathrm{L}$ buffer, and $360 \mu \mathrm{L}$ substrate.

$$
\text { Inhibition }=\left(\frac{N-I}{N}\right) \times 100
$$

where $N$ is the activity of the native enzyme and $I$ is the activity of the enzyme in the presence of inhibitor.

\section{Results}

Qualitative phytochemical analysis

Table 1 shows the secondary metabolites present in hexane, methanol, and water extracts of the plant. 
Table 1 Qualitative phytochemical analysis of root and aerial parts of $V$. coriaceum

\begin{tabular}{|c|c|c|c|c|c|c|}
\hline \multirow{2}{*}{$\begin{array}{l}\text { Secondary } \\
\text { metabolites }\end{array}$} & \multicolumn{3}{|l|}{ Root } & \multicolumn{3}{|c|}{ Aerial parts } \\
\hline & Hexane & Methanol & Water & Hexane & Methanol & Water \\
\hline Alkaloids & - & + & + & - & + & - \\
\hline Flavonoids & + & + & - & + & + & - \\
\hline Tannins & + & + & - & - & + & + \\
\hline Triterpenoids & + & + & - & + & + & + \\
\hline Glycosides & + & + & + & + & + & + \\
\hline Saponins & - & - & + & - & + & + \\
\hline Anthocyanins & - & - & - & - & - & - \\
\hline
\end{tabular}

Glycosides, indifferent to dielectric nature of the solvents, were present in all the extracts. Triterpenoids were absent in water showing their insolubility in polar solvents. The other categories of compounds showed inconsistent solubility preferences probably gained by complex formation and it reflects the presence/absence of certain types in root or aerial parts of the plant.

\section{Quantitative phytochemical analysis}

Total amount of the phytochemicals present in the plant samples were estimated. Alkaloids, flavonoids, phenols, and tannins were estimated using their corresponding standards. Results are shown in Table 2.

\section{Alkaloids}

The amount of alkaloids present in $2.5 \mathrm{~g}$ of the roots and aerial parts were analyzed and the results obtained showed $5.06 \pm 0.3 \%$ alkaloids in the root and $1.63 \pm$ $0.35 \%$ in the aerial parts.

\section{Flavonoids}

Flavonoid content was measured as the absorbance of aluminium chloride-flavonoid complexes formed using a spectrophotometer. It was found that hexane and methanol extracts of root contain $105 \pm 7.07 \mu \mathrm{g} / \mathrm{mL}$ and $156 \pm 4.2 \mu \mathrm{g} / \mathrm{mL}$ respectively while that of aerial parts contained $108 \pm 5.08 \mu \mathrm{g} / \mathrm{mL}$ and $197 \pm 1.41 \mu \mathrm{g} / \mathrm{mL}$.

\section{Tannins}

Hexane and methanol extract of the roots and methanol and water extracts of the plant aerial parts showed the presence of tannins. Hexane and methanol extracts of root contained $156 \pm 3.89 \mu \mathrm{g} / \mathrm{mL}$ and $315 \pm 6.07 \mu \mathrm{g} / \mathrm{mL}$ respectively. Methanol and water extracts of the aerial parts contained $385 \pm 4.17 \mu \mathrm{g} / \mathrm{mL}$ and $135 \pm 7.7 \mu \mathrm{g} / \mathrm{mL}$ respectively.

\section{Phenols}

Total phenol contents in the plant extracts were measured spectrophotometrically. Hexane, methanol, and water extracts of the plant root contained $12 \pm 2.7 \mu \mathrm{g} / \mathrm{mL}, 28.5 \pm$ $1.41 \mu \mathrm{g} / \mathrm{mL}$, and $16.25 \pm 3.8 \mu \mathrm{g} / \mathrm{mL}$ of phenols while that of the aerial parts contained $19.25 \pm 1.7 \mu \mathrm{g} / \mathrm{mL}, 29.75 \pm$ $1.06 \mu \mathrm{g} / \mathrm{mL}$, and $21.5 \pm 5.6 \mu \mathrm{g} / \mathrm{mL}$ respectively.

\section{In vitro anti-oxidant assays}

Methanol and hexane extracts of the plant parts showed a considerable activity against various anti-oxidant targets.

\section{DPPH radical scavenging assay}

Plant extracts showed different potential in DPPH scavenging. Methanol extract of root and hexane extract of aerial parts showed higher activity when compared to other extracts. DPPH scavenging activity of the plant extracts at different concentrations are also showed in the graph (Fig. 1). $\mathrm{IC}_{50}$ and ascorbic acid equivalence of the extracts were calculated using the standard graph and are shown in Table 3.

\section{ABTS radical scavenging assay}

ABTS radical generated in the reaction system were scavenged by the anti-oxidants present in the sample. Decolorization of the solution in accordance with the amount of anti-oxidants in the samples was measured as

Table 2 Quantitative phytochemical analysis of root and aerial parts of $V$. coriaceum

\begin{tabular}{|c|c|c|c|c|c|c|}
\hline \multirow{2}{*}{$\begin{array}{l}\text { Secondary } \\
\text { metabolites }\end{array}$} & \multicolumn{3}{|l|}{ Root } & \multicolumn{3}{|l|}{ Aerial parts } \\
\hline & Hexane $(\mu \mathrm{g} / \mathrm{mL})$ & Methanol $(\mu \mathrm{g} / \mathrm{mL})$ & Water $(\mu \mathrm{g} / \mathrm{mL})$ & Hexane $(\mu \mathrm{g} / \mathrm{mL})$ & Methanol $(\mu \mathrm{g} / \mathrm{mL})$ & Water $(\mu \mathrm{g} / \mathrm{mL})$ \\
\hline Flavonoids & $105 \pm 7.07$ & $156 \pm 4.2$ & 0.0 & $108 \pm 5.08$ & $197 \pm 1.41$ & 0.0 \\
\hline Tannins & $156 \pm 3.89$ & $315 \pm 6.07$ & 0.0 & 0.0 & $385 \pm 4.17$ & $135 \pm 7.7$ \\
\hline Phenols & $12 \pm 2.7$ & $28.5 \pm 1.41$ & $16.25 \pm 3.8$ & $19.25 \pm 1.7$ & $29.75 \pm 1.06$ & $21.5 \pm 5.6$ \\
\hline Alkaloids & \multicolumn{3}{|c|}{$5.06 \pm 0.3 \%$ per $2.5 \mathrm{~g}$ powder } & \multicolumn{3}{|c|}{$1.63 \pm 0.35 \%$ per $2.5 \mathrm{~g}$ powder } \\
\hline
\end{tabular}




\section{DPPH Scavenging activity at different extract concentrations}

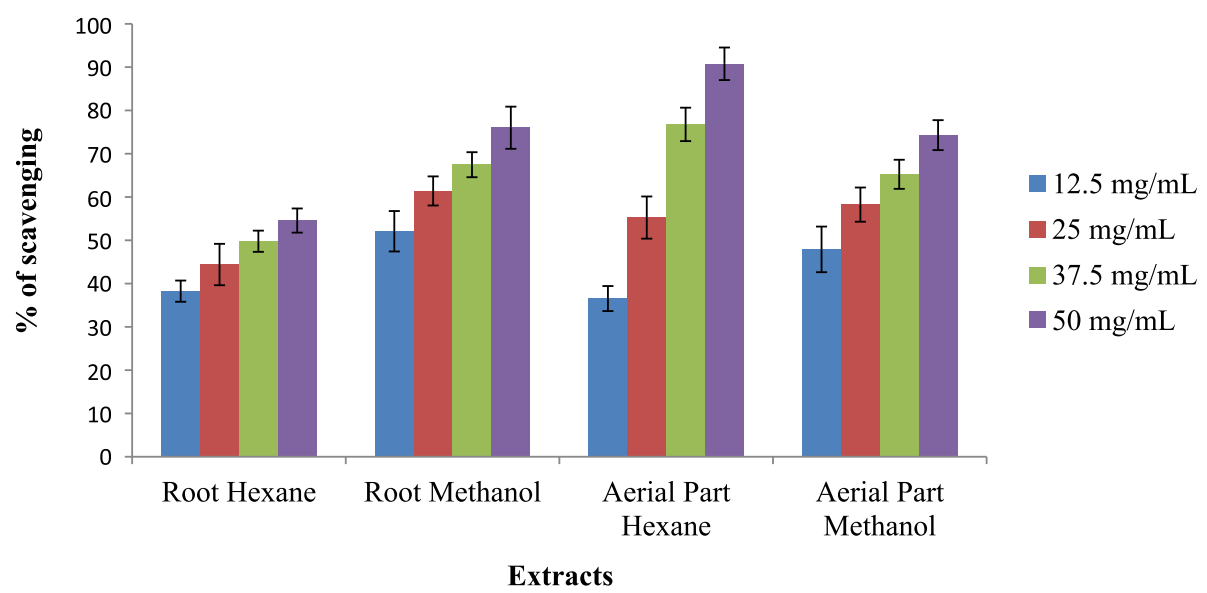

Fig. 1 DPPH scavenging activity of different extracts of $V$. coriaceum at different concentrations

change in the absorbance at $734 \mathrm{~nm}$. In the bar diagram (Fig. 2), percentage of scavenging was found to be high for methanolic extracts of the root and aerial parts. $\mathrm{IC}_{50}$ and ascorbic acid equivalence of all the extracts are represented in the Table 4 .

\section{Hydroxyl radical scavenging assay}

The absorbance of hydroxylated salicylate and changes in absorbance at different extract concentrations were measured. Percentage of scavenging hydroxyl radicals showed that methanolic extract of the root and hexane extract of the aerial parts were more active in this regard. Activity at different extract concentrations were expressed in the graph (Fig. 3), $\mathrm{IC}_{50}$, and ascorbic acid equivalence were shown in the Table 5.

\section{In vitro anti-bacterial assay}

Clinical strains of Escherichia coli, Pseudomonas sp., and Klebsiella sp. showed a well-developed zone of inhibition at very low concentration of root extract with methanol (Fig. 4). There was a linear increase in the inhibition zone with increase in the concentration of the samples. Wells $1,2,3$, and 4 indicate the folds of increase of the

Table $3 \mathrm{I} C_{50}$ and ascorbic acid equivalence of the extracts of $V$. coriaceum in DPPH scavenging activity

\begin{tabular}{lll}
\hline Extracts & $\begin{array}{l}\mathrm{IC}_{\mathbf{5 0}} \text { values } \\
(\mathbf{m g} / \mathbf{m L})\end{array}$ & $\begin{array}{l}\text { Ascorbic acid equivalence } \\
\text { in } \mathbf{m g} / \mathbf{m L}(\mathbf{1 2 . 5} \mathbf{~ m g} / \mathbf{m L} \\
\text { of extract })\end{array}$ \\
\hline Root-Hexane & 37.5 & 0.018 \\
Root-Methanol & 11 & 0.029 \\
Aerial parts-Hexane & 21 & 0.016 \\
Aerial parts-Methanol & 15 & 0.025 \\
\hline
\end{tabular}

root extract with methanol added with the bacterial samples and well B being blank.

\section{In vitro anti-inflammatory assays}

The inhibitory property of the plant extracts showed on enzymes trypsin (Fig. 5) and LOX (Fig. 6) could be considered contributing to its anti-inflammation property. Root-hexane extract showed highest trypsin inhibition (95.26\%) followed by chloroform $(71.35 \%)$ and rootmethanol showed highest inhibition for LOX (79.54\%) followed by hexane (72.61\%).

\section{Discussion}

Present study was focused mainly on exploring a little known plant of the genus Viburnum. This work has impacted in opening up of probable important medicinal properties of $V$. coriaceum. Phytochemical screening and their quantitative estimations were performed as an initial step of study. Bioactive compounds reported from other members of the same genus strengthened the scope of study. In vitro anti-oxidant, anti-bacterial, and anti-inflammatory activities were selected as indicative of the applicability of plant material.

Successively prepared hexane, methanol, and water extracts of the roots and aerial parts of $V$. coriaceum were used for qualitative analysis (Table 1). Presence of alkaloids, flavonoids, tannins, triterpenoids, glycosides, and saponins were found in the plant analyzed. Anthocyanins could not be detected in any of the extracts analyzed. Hence, it may be concluded that anthocyanins may not be present in the sample analyzed. Methanol extract of both root and aerial parts were found to be relatively high in phytoconstituents. In the root extracts studied, hexane extract possesses flavonoids, tannins, triterpenoids, and glycosides; methanol extract possesses 


\section{ABTS scavenging activity at different extract concentrations}

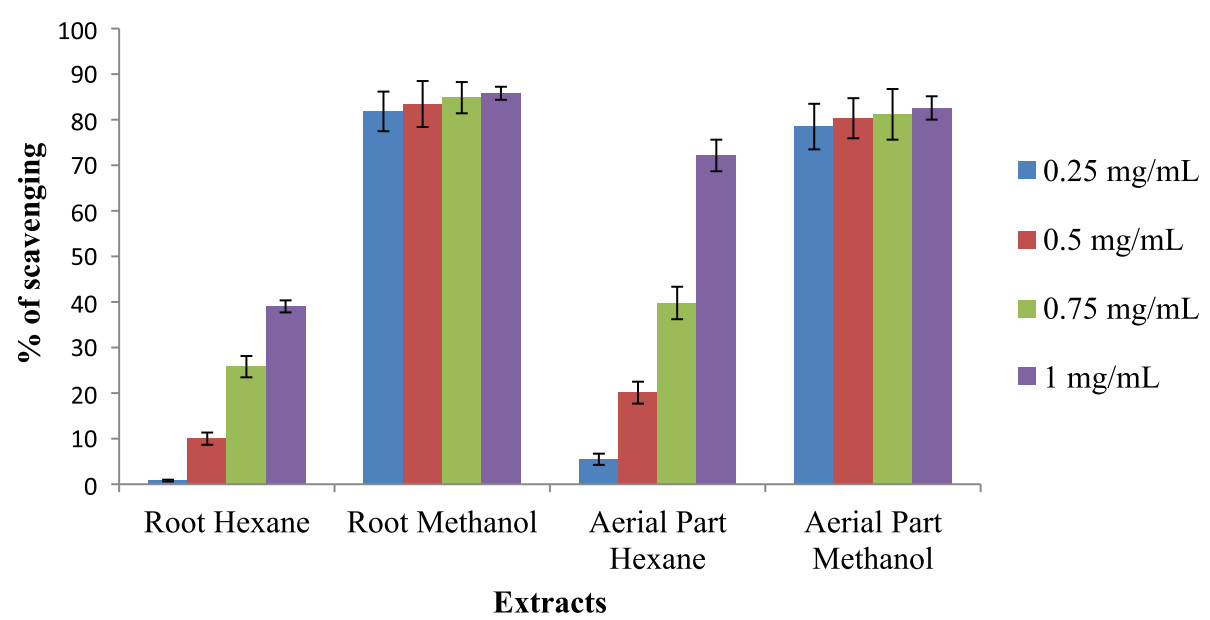

Fig. 2 ABTS scavenging activity of different extracts of $V$. coriaceum at different concentrations

alkaloids, flavonoids, tannins, triterpenoids, and glycosides; and water extract possesses only alkaloids, glycosides, and saponins. In the case of aerial parts, hexane extract possesses only flavonoids, triterpenoids, and glycosides; methanol extract possesses alkaloids, flavonoids, tannins, triterpenoids, glycosides, and saponins; and water extract possesses tannins, triterpenoids, glycosides, and saponins.

In an earlier study of comparative phytochemical screening of leaf, stem, and root of three different Viburnum sp., leaf extract of $V$. coriaceum showed relatively larger concentration of triterpenoids, phytosterols, and carbohydrates; stem extracts showed higher concentration of triterpenoids and carbohydrates along with presence of glycosides, flavonoids, and phenolics [37]. The present study also showed the presence of triterpenoids, glycosides, flavonoids, and other phenolics in the aerial parts (leaf and stem together) of the plant. The sequential extraction by solvent of increasing polarity, which would help purification of the targeted molecules was not considered by the previous group. Root extract of the plant reported formerly was with the presence of carbohydrates, saponins, phenolics, alkaloids,

Table $4 \mid C_{50}$ and ascorbic acid equivalence of the extracts of $V$. coriaceum in ABTS scavenging activity

\begin{tabular}{lll}
\hline Extracts & $\begin{array}{l}\mathrm{I} \mathbf{C}_{\mathbf{5 0}} \text { values } \\
(\mathbf{m g} / \mathbf{m L})\end{array}$ & $\begin{array}{l}\text { Ascorbic acid equivalence } \\
\text { in } \mathbf{~ g} / \mathbf{m L}(\mathbf{0 . 2 5} \mathbf{~ m g} / \mathbf{m L} \\
\text { of extract })\end{array}$ \\
\hline Root-Hexane & 1.46 & 0.22 \\
Root-Methanol & 0.16 & 1.94 \\
Aerial parts-Hexane & 0.7 & 0.17 \\
Aerial parts-Methanol & 0.17 & 1.88 \\
\hline
\end{tabular}

triterpenoids, sterols, and glycosides [37]. The present observation was conforming to that, however, the present results has shown better suggestion to purify the different classes and phyto compounds. Seventy percent ethanol extract of $V$. coriaceum, in comparison to current findings, had been demonstrated to possess flavonoids, tannins, glycosides, saponins, and anthocyanins, but not alkaloids and triterpenoids [19]. This could be due to the difference in the use of solvents or any other phenomenon that might influence the presence of secondary metabolites in plants. Qualitative phytochemical analysis conducted with different extracts of $V$. opulus, a species closely related to $V$. coriaceum also showed the presence of tannins, saponins, alkaloids, flavonoids, glycosides, phenols, terpenoids, and steroids [38]. Many researchers have reported the biological activities of these groups of compounds from the plants. Thus strengthened the scope of further analysis in V. coriaceum.

Mere presence of a particular group of compound cannot support the medicinal value of a plant. Hence, next stage of the study focused on the total content of some of the main group of compounds. Phenols including flavonoids and tannins were reported to play major role in the anti-oxidant activities and in turn for the treatment of many chronic diseases [39] are included in the study along with alkaloids. Alkaloids were also reported with various bioactivities like anti-cholinergic, anti-hypertensive, anti-inflammatory, anti-neoplastic activities, etc. [40]. A comparative analysis was conducted among the different extracts (hexane, methanol and water) of roots and aerial parts (Table 2) in the current study. Methanol extracts leads in total phenol, flavonoid and tannin contents than the other extracts studied. Also, tannin 
Hydroxyl radical scavenging activity at different extract concentrations

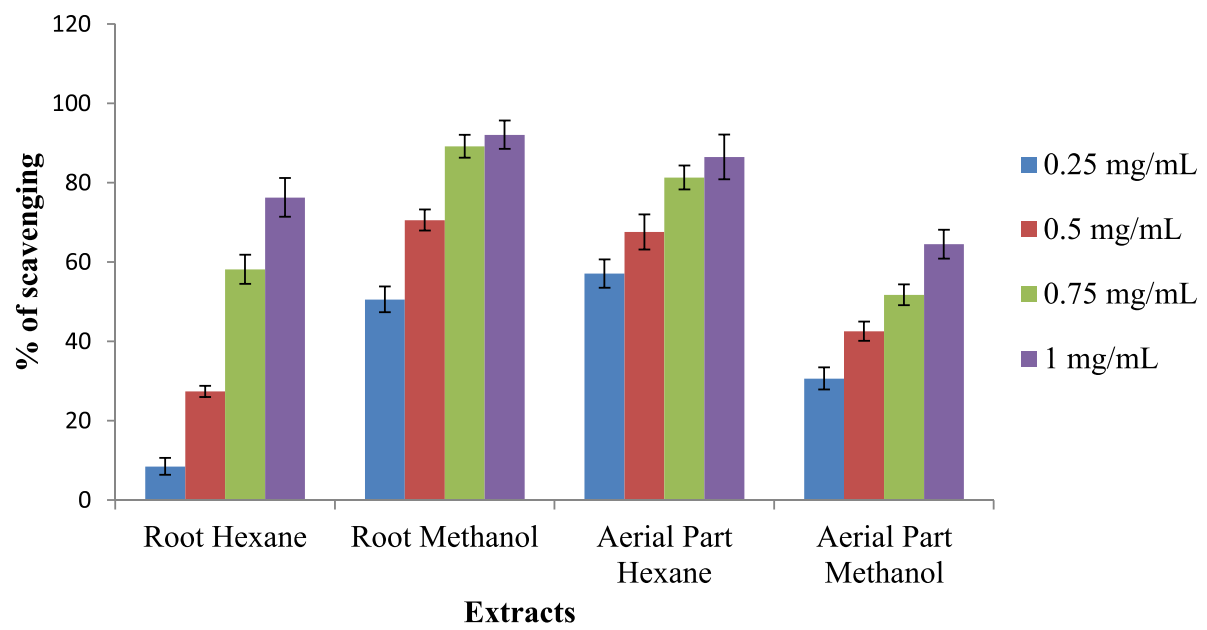

Fig. 3 Hydroxyl radical scavenging activity of different extracts of $V$. coriaceum at different concentrations

content was found to be higher than other groups of compounds which were $315 \pm 6.07 \mu \mathrm{g} / \mathrm{mL}$ and $385 \pm$ $4.17 \mu \mathrm{g} / \mathrm{mL}$ in the methanol extracts of roots and aerial parts respectively. This comparative analysis among extracts could not be done in total alkaloid content as the procedure needed plant powder as such. In this, roots and aerial parts were analyzed separately and showed $5.06 \pm 0.3 \%$ and $1.63 \pm 0.35 \%$ of alkaloids per $2.5 \mathrm{~g}$ of plant powder respectively. A total phenol content of $11 \pm 0.52 \mathrm{mg} / \mathrm{g}$ was reported from whole plant powder [41], as in the preset report. Data from closely related species also showed high content of phenolic compounds like flavonoids and tannins in viburnums and accounts for many of its biological activities. According to the presently acquired data, $V$. coriaceum is of great significance in this regard.

Uncontrolled production of free radicals is a common phenomenon in many of the patho-physiological conditions of mammalian cells. This may be due to impairment in the endogenous anti-oxidant mechanism, damages in the cells, and exposure to various oxidizing agents [42]. Hence, scavenging of the free radicals could reduce the severity of unhealthy conditions. Anti-

Table $\mathbf{5} I C_{50}$ and ascorbic acid equivalence of the extracts of $V$. coriaceum in hydroxyl radical scavenging

\begin{tabular}{lll}
\hline Extracts & $\begin{array}{l}\mathrm{IC}_{50} \text { values } \\
(\mathbf{m g} / \mathbf{m L})\end{array}$ & $\begin{array}{l}\text { Ascorbic acid equivalence } \\
\text { in } \mathbf{~} \mathbf{g} / \mathbf{m L}(\mathbf{0 . 2 5} \mathbf{~ m g} / \mathbf{m L} \\
\text { of extract })\end{array}$ \\
\hline Root-Hexane & 0.68 & 0.0045 \\
Root-Methanol & 0.25 & 0.027 \\
Aerial parts-Hexane & 0.14 & 0.030 \\
Aerial parts-Methanol & 0.73 & 0.019 \\
\hline
\end{tabular}

oxidant compounds are the main scavengers of such free radicals [43]. Free radicals being different chemical entities require different tests to prove the scavenging capacity of the plant extracts through different mechanisms [44]. DPPH, ABTS, and hydroxyl radical scavenging activity of the different extracts of roots and aerial parts of $V$. coriaceum were examined here. Plant extracts in different solvents showed different potential in scavenging free radicals (Figs. 1, 2, and 3). Water extracts showed less or no activity in all the three experiments performed and hence it was not included in the results.

DPPH radical scavenging activity was measured first. Discoloration of the deep purple color of DPPH solution into golden yellow color by absorbing hydrogen from the donors was the indication used for identifying the presence of radical scavengers in the extract. In the experiment, it was observed that both the hexane and methanol extracts showed the potential to scavenge DPPH radicals (Fig. 1). At lower concentrations (12.5 $\mathrm{mg} / \mathrm{mL}$ ), methanol extract of root showed the highest activity and hexane extract of aerial parts showed lowest activity. But with the increase in concentration of extracts, there was only a slight increase in activity observed in the methanol extract of root. Whereas in hexane extract of aerial parts, a high rate of increase in activity was observed with increase in concentration. Hence at the highest concentration $(50 \mathrm{mg} / \mathrm{mL})$, hexane extract of aerial parts showed the highest activity. Both the other two extracts (root-hexane and aerial-parts methanol) showed a pattern similar to that of rootmethanol extract.

ABTS radical scavenging activity was the next test performed for analyzing the anti-oxidant potential. This is also a color based test. Dark blue green color of ABTS solution got decolorized by the radical scavengers in the 


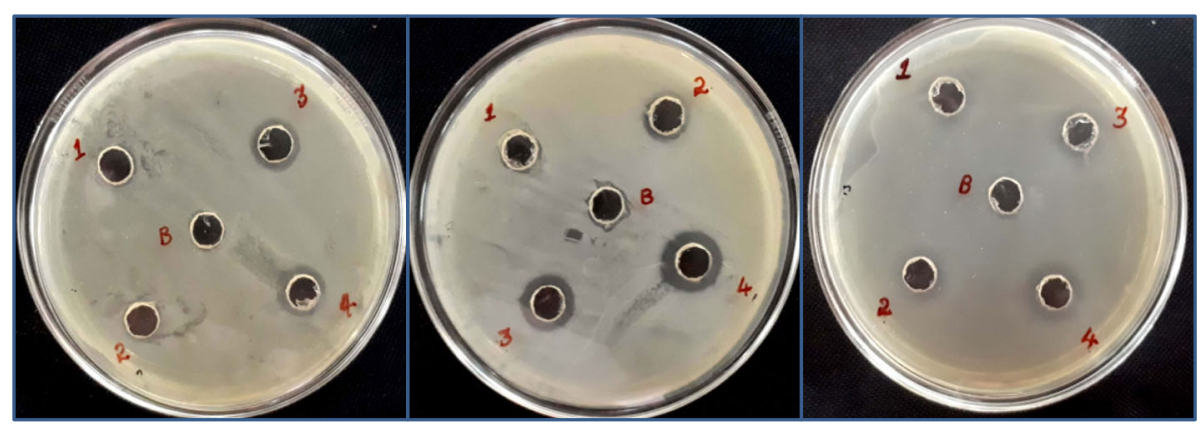

(a)

(b)

(c)

Fig. 4 Anti-bacterial activity of different concentrations of the methanolic extract of plant root. a Escherichia coli. b Klebsiella sp. c Pseudomonas sp.

extract. Root-methanol and aerial parts-methanol extracts showed a high percentage of activity (Fig. 2). Both the extracts showed a very high free radical scavenging activity at the lowest concentration $(0.25 \mathrm{mg} / \mathrm{mL})$ itself and not much difference was observed in the activity with increase in concentration. This shows its high free radical scavenging activity even at very low concentration. But with root-hexane and aerial parts-hexane extract, rate of increase in activity with increasing concentration was high. Though they showed only a very low activity at the lowest concentration $(0.25 \mathrm{mg} / \mathrm{mL})$, activities reached a better level at highest concentration $(1 \mathrm{mg} / \mathrm{mL})$, especially in the case of aerial parts-hexane extract.

Under hypoxia, living organisms produce the most biologically active hydroxyl radicals. They affect nucleic acid and protein structures and play major roles in the negative progression of many chronic diseases like atherosclerosis, neurodegenerative diseases, cancer, etc. [33, 45]. Hence, hydroxyl radical scavengers are very important in life saving medications. In the current study, root- methanol and aerial parts-hexane extracts showed a similar pattern in their activity. With increase in concentration of extracts, the rate of activity increases (Fig. 3). Both these extracts scored higher values compared to the other extracts. Aerial parts-methanol extract also scored a higher value. Root-hexane extract, though showed a very low activity at lowest concentration $(0.25$ $\mathrm{mg} / \mathrm{mL}$ ) of extract, it showed increase in activity with higher concentration. It showed an appreciably better value at the highest concentration $(1 \mathrm{mg} / \mathrm{mL})$.

In a comparative view on all the three tests of antioxidant activities, ABTS and hydroxyl radicals were scavenged at low concentration of extracts than DPPH radicals. Highest concentration employed for ABTS and hydroxyl radical scavenging were $1 \mathrm{mg} / \mathrm{mL}$. For DPPH, it was $50 \mathrm{mg} / \mathrm{mL}$, showing that DPPH assay is not sensitive in the case of $V$. coriaceum. Out of the extracts studied, root-methanol extract showed consistently a good free radical scavenging potential in all the tests. In $\mathrm{DPPH}$, radical scavenging root-methanol $\left(\mathrm{IC}_{50}-11 \mathrm{mg} /\right.$ $\mathrm{mL}$ ) showed the highest activity (Table 3); in ABTS

\section{Trypsin inhibitory activity of different extracts of $V$. coriaceum root}

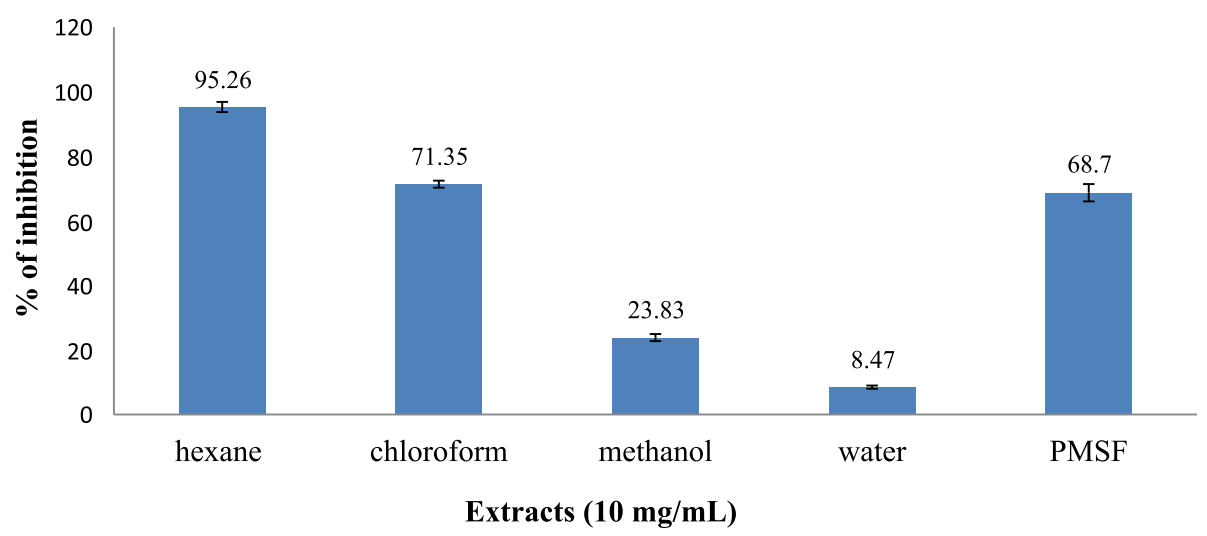

Fig. 5 Trypsin inhibition showed by different extracts of $V$. coriaceum 


\section{LOX inhibitory activity of different extracts of $V$. coriaceum root}

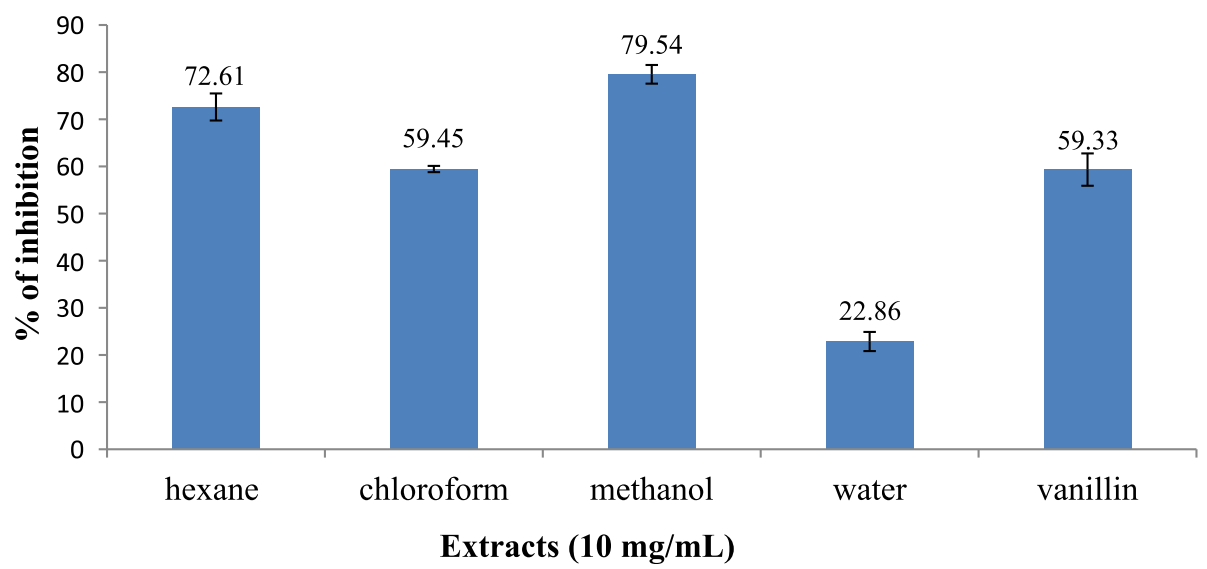

Fig. 6 LOX inhibition showed by different extracts of $V$. coriaceum

(Table 4), radical scavenging both root $\left(\mathrm{IC}_{50}-0.16 \mathrm{mg} /\right.$ $\mathrm{mL})$ and aerial parts $\left(\mathrm{IC}_{50}-0.17 \mathrm{mg} / \mathrm{mL}\right)$ methanol extracts showed higher activity. In hydroxyl radical scavenging (Table 5), root-methanol extract ( $\mathrm{IC}_{50}-0.25 \mathrm{mg} /$ $\mathrm{mL})$ comes next to aerial parts-hexane extract $\left(\mathrm{IC}_{50}-\right.$ $0.14 \mathrm{mg} / \mathrm{mL}$ ). The differences observed may be due to the mode of interaction directed by the structure and amount of anti-oxidants present in the extracts. Ascorbic acid, the standard anti-oxidant can reduce free radicals at a faster rate compared to other anti-oxidants [46]. $V$. coriaceum showed a significant anti-oxidant potential compared to the standard, in a study of different Viburnum sp. [41]. The present study provides better and comprehensive data than the previous attempt. Total phenolic content of the plant also contributed to its anti-oxidant potential. There is a significant correlation existing between the anti-oxidant capacity of a plant and its total phenolic content [47]. High phenolic content observed in the methanolic extracts of the roots and aerial parts in the present analysis of $V$. coriaceum corresponds to the observation referenced above [47]. Chlorogenic acid, a potent anti-oxidant phenolic compound [48], had been isolated from the stems of $V$. coriaceum [49].

Viburnums were widely studied for their anti-bacterial activity. Many of them showed significant activity against pathogenic bacteria like Staphylococcus aureus, Bacillus subtilis, Escherichia coli, Salmonella sp., Pseudomonas aeroginosa, Klebsiella pneumonia, etc. [11, 50]. Out of the extracts studied, root-methanol showed the highest activity. All the other extracts showed little or no inhibition. Anti-bacterial activity of V. coriaceum showed inhibitory potential on Escherichia coli, Pseudomonas sp., and Klebsiella sp. at lower concentrations (Fig. 4). Staphylococcus aureus was also inhibited but at a very high concentration. A correlation between tannin content with anti-microbial property of plants have been reported by a group of researchers. Plant species which were popularly known for anti-microbial activities were found to possess tannin content above than average [51] and anti-microbial activity of tannins was also reported by many $[52,53]$. Current study also supports this data as the extract (root-methanol) which showed high antibacterial activity also possesses high tannin content (Table 2). Gomojosides with potent anti-bacterial activity were isolated from many Viburnums [16]. Amentoflavone and astragalin isolated from the roots of $V$. erubescens were found to be effective against many human pathogens [41].

Anti-inflammatory activity of $V$. coriaceum was studied in vitro with different extracts (hexane, chloroform, methanol, and water) of roots and aerial parts. Trypsin and LOX inhibition potential was the target for anti-inflammatory activity. Root extracts showed higher inhibition than the aerial parts; hence, in the results (Figs. 5 and 6), different extracts of roots were only included. Hexane extract of root showed the highest inhibition on trypsin, chloroform, and methanol extracts comes next (Fig. 5). Whereas, LOX inhibition was more pronounced with the root-methanol extract followed by hexane extract (Fig. 6). This would serve as a guide to the isolation of the active inhibitory compound/s and it may be assumed that they could be different for trypsin and LOX.

Enzymes trypsin and LOX were experimentally preferred as the target for studying anti-inflammatory potential. Trypsin is a serine protease associated with inflammation, digestion, osteoarthritis, various neurological disorders, etc. as it can break down a number of proteins with pivotal roles in normal functioning of the 
body [54]. Inhibition of proteases can play significant role in reducing the complications of many pathophysiological conditions where inflammation is implied [55]. LOX being a crucial member of the arachidonic acid pathway of inflammatory reactions is the most commonly used target of anti-inflammatory studies [56]. An Ayurvedic preparation (Churna) from the roots of three Viburnum sp.- $V$. coriaceum, $V$. erubescens, $V$. punctatum showed effective anti-inflammatory activity in animal models. The probable mechanism of this in vivo anti-inflammatory activity was explained as the inhibition of enzymes in the phospholipid metabolism pathways like phospholipase A2, cycloxygenase, LOX, and acetyl transferase [41]. Plant's inhibition potential of these enzymes may lead to its effective use in the treatment of many disorders, by finding out of drugs/drugleads. The significance of the work presented here implicates its second phase of finding the active principles and their more active derivatives.

\section{Conclusion}

The chemical constituents and the bioactivities of $V$.coriaceum $\mathrm{Bl}$. showed it as a highly promising medicinal plant. As the anti-oxidant and anti-inflammatory potential of the plant extracts are appreciable, it can also be considered for investigating anti-cancerous activities. Out of all the extracts studied, methanol extracts of the plant parts showed high anti-oxidant activity. Hexane extract of the plant root possesses a high amount of anti-inflammatory activity. It showed an inhibition above $70 \%$ of the two pro-inflammatory enzymes studied. Hence, further studies could be planned to focus on its anti-inflammatory potential expressed by hexane extract, for isolating promising drug leads.

\footnotetext{
Abbreviations

CMPR: Centre for Medicinal Plants Research; DPPH: 1,1-Diphenyl-2picrylhydrazyl; ABTS: 2, 2'-azinobis (3-ethylbenzothiazoline)-6-sulfonic acid; ROS: Reactive oxygen species; DMSO: Dimethyl sulfoxide; BAEE: $N_{a}$-benzoyl-Larginine ethyl ester; PMSF: Phenyl methyl sulfonyl fluoride; $\mathrm{HCl}$ : Hydrochloric acid; LOX: Lipoxygenase
}

\section{Acknowledgements \\ The authors gratefully acknowledge Inter University Centre for Biosciences and Department of Biotechnology and Microbiology, Kannur University for providing the infrastructure and other facilities. W acknowledges the financial support of the Kannur University.}

\section{Permission for plant collection and study}

The authors procured permission from the Forest Department, Govt. of Kerala, India to visit and collect the plant sample from the forest areas for the research purposes as per the Order No. WL 10-47474/2014 dated 1/12/ 2015 and accordingly procured the sample for study.

\section{Authors' contributions}

The authors declare that all the works stated in the article were done by themselves. W performed all the experimental works and compiled the data and ARV assisted $\mathrm{W}$ in performing all the work. $\mathrm{MH}$ conceived the research program, and guided the work. MH gave final shape to the manuscript. All the authors have read and approved the final manuscript.

\section{Funding}

No funding was received.

\section{Availability of data and materials}

The data used to support the findings of this study are available from the corresponding author upon request.

Ethics approval and consent to participate

Not applicable. This research article does not contain any studies using animals or human.

\section{Consent for publication}

Not applicable.

\section{Competing interests}

The authors declare that they have no competing interests.

\section{Author details}

${ }^{1}$ Department of Biotechnology and Microbiology, Kannur University, Thalassery 670661, Kerala, India. ${ }^{2}$ Inter University Centre for Biosciences, Kannur University, Thalassery 670661, Kerala, India.

Received: 25 October 2019 Accepted: 31 August 2020

Published online: 12 November 2020

\section{References}

1. Iqbal Awan Zahid lqbal Awan Z (2013) Ethnobotanical importance of some highly medicinal plants of district Muzaffarabad, Pakistan with special reference to the Species of the Genus Viburnum. IOSR J Pharm Biol Sci 6: 53-66. https://doi.org/10.9790/3008-0625366

2. Konarska A (2017) Comparative micromorphology and anatomy of flowers and floral secretory structures in two Viburnum species. Protoplasma 254(1): 523-537. https://doi.org/10.1007/s00709-016-0972-0

3. Romm A (2010) Chapter 13 - pregnancy: first trimester. In: Romm A, Hardy ML, Mills $S$ (eds) Botanical medicine for women's health. Churchill Livingstone, Saint Louis, pp 347-361. https://doi.org/10.1016/B978-0-44307277-2.00015-5

4. Zengion AH, Yarnell E (2011) 20 - Herbal and nutritional supplements for painful conditions. In: Lennard TA, Walkowski S, Singla AK, Vivian DG (eds) Pain procedures in clinical practice, 3rd edn. Hanley \& Belfus, Saint Louis, pp 187-204. https://doi.org/10.1016/B978-1-4160-3779-8.10020-X

5. Pellow J (2016) The efficacy of Viburnum opulus $3 X$ in the treatment of primary dysmenorrhea-full text view - ClinicalTrials.gov. https://clinicaltrials. gov/ct2/show/NCT02467543. Accessed 4 Sept 2019.

6. William B (1999) Viburnum opulus - Homoeopathic Materia Medica. http:// www.homeoint.org/books/boericmm/v/vib.htm. Accessed 4 Sept 2019.

7. Altun ML, Citoglu GS, Yilmaz BS, Coban T (2008) Antioxidant properties of Viburnum opulus and Viburnum lantana growing in Turkey. Int J Food Sci Nutr 59(3):175-180. https://doi.org/10.1080/09637480701381648

8. Shao J-H, Chen J, Xu X-Q, Zhao C-C, Dong Z-L, Liu W-Y, Shen J (2019) Chemical constituents and biological activities of Viburnum macrocephalum f. keteleeri. Nat Prod Res 33(11):1612-1616. https://doi.org/10.1080/ 14786419.2018.1428593

9. Alam M, Uddin G, Sadat A, Muhammd N, Khan AA, Siddiqui BS, Ebrahim H (2012) Evaluation of Viburnum grandiflorum for its in-vitro pharmacological screening. Afr J Pharm Pharmacol 6(22):1606-1610. https://doi.org/10.5897/ AJPP12.316

10. Iwai K, Onodera A, Matsue H (2004) Inhibitory effects of Viburnum dilatatum Thunb. (Gamazumi) on oxidation and hyperglycemia in rats with streptozotocin-induced diabetes. J Agric Food Chem 52(4):1002-1007. https://doi.org/10.1021/jf0302557

11. Eryllmaz M, Ozbilgin S, Ergene B, Yilmaz B, Altun M, Citoglu G (2013) Antimicrobial activity of Turkish Viburnum Species. Bangladesh J Bot 42 : 355-360. https://doi.org/10.3329/bjb.v42i2.18044

12. Altun ML, Citoglu GS, Yilmaz BS, Ozbek H (2009) Antinociceptive and antiinflammatory activities of Viburnum opulus. Pharm Biol 47(7):653-658. https://doi.org/10.1080/13880200902918345

13. Chen J, Shao J, Zhao C, Shen J, Dong Z, Liu W, Zhao M, Fan J (2018) Chemical constituents from Viburnum fordiae Hance and their antiinflammatory and antioxidant activities. Arch Pharm Res 41(6):625-632. https://doi.org/10.1007/s12272-018-1026-2 
14. Altun M, Ozbek H, Citoglu G, Yilmaz B, Bayram I, Cengiz N (2010) Hepatoprotective and hypoglycemic activities of viburnum opulus L. Turk J Pharm Sci 7:35-48

15. Dietz BM, Hajirahimkhan A, Dunlap TL, Bolton JL (2016) Botanicals and their bioactive phytochemicals for women's health. Pharmacol Rev 68(4):1026. https://doi.org/10.1124/pr.115.010843

16. Wang L-Q, Chen Y-G, Xu J-J, Liu Y, Li X-M, Zhao Y (2018) Compounds from Viburnum species and their biological activities. Chem Biodivers 5:18791899. https://doi.org/10.1002/cbdv.200890175

17. Viburnum coriaceum Bl. India Biodiversity Portal. https://indiabiodiversity. org/species/show/250950. Accessed 5 Sept 2019

18. Clement W, Arakaki M, Sweeney P, Edwards EJ, Donoghue MJ (2014) A chloroplast genome tree for Viburnum (Adoxaceae): implications for character evolution and phylogenetic classification. Am J Bot 101:10291049. https://doi.org/10.3732/ajb.1400015

19. Prabhu K, Ponnudurai K (2011) Formulation of viburnum coriaceum arista and determination of its anticonvulsant activity in mice. Pharm $\operatorname{Sin} 2(4)$ http://www.imedpub.com/abstract/formulation-of-viburnum-coriaceumarista-and-determination-of-its-anticonvulsant-activity-in-mice-16995.html. Accessed 5 Sept 2019

20. Harborne AJ (1998) Phytochemical methods a guide to modern techniques of plant analysis, 3rd edn. Springer Netherlands https://www.springer.com/ gp/book/9780412572609. Accessed 5 Sept 2019

21. Morsy N (2014) Phytochemical analysis of biologically active constituents of medicinal plants. Main Group Chem 13:7-21. https://doi.org/10.3233/MGC130117

22. Santhi KS, Sengottuvel R (2016) Qualitative and quantitative phytochemical analysis of Moringa concanensis Nimmo. Int J Curr Microbiol Appl Sci 5: 633-640. https://doi.org/10.20546/ijcmas.2016.501.064

23. Gul R, Jan SU, Faridullah S, Sherani S, Jahan N (2017) Preliminary phytochemical screening, quantitative analysis of alkaloids, and antioxidant activity of crude plant extracts from Ephedra intermedia Indigenous to Balochistan [Research Article]. Sci World J. https://doi.org/10.1155/2017/ 5873648

24. Rajesh KD, Vasantha S, Rajesh NV, Panneerselvam A (2014) Qualitative and quantitative phytochemical analysis in four pteridophytes. Int J Pharm Sci Rev Res 27:408-412

25. Chang CC, Yang MH, Wen HM, Chern JC (2002) Estimation of total flavonoid content in propolis by two complementary colorimetric methods. J Food Drug Anal 10(3):178-182.

26. Sari A, Elya B, Elya B, Elya B (2017) Antioxidant activity and lipoxygenase enzyme inhibition assay with total flavonoid assay of Garcinia porrecta Laness. stem bark extracts. Pharmacogn J 9(2):257-266. https://doi.org/10. 5530/pj.2017.2.44

27. Prabhavathi RM, Prasad MP, Jayaramu M (2016) Studies on qualitative and quantitative phytochemical analysis of Cissus quadrangularis. Pelagia Res Libr Adv Appl Sci Res 7(4):11-17

28. Ci KC, Indira G (2016) Quantitative estimation of total phenolic, flavonoids, tannin and chlorophyll content of leaves of Strobilanthes Kunthiana (Neelakurinji). J Med Plants Stud 4(4):282-286

29. Anesini C, Ferraro GE, Filip R (2008) Total polyphenol content and antioxidant capacity of commercially available tea (Camellia sinensis) in Argentina. J Agric Food Chem 56(19):9225-9229. https://doi.org/10.1021/ jf8022782

30. Blainski A, Lopes GC, De Mello JCP (2013) Application and analysis of the Folin Ciocalteu method for the determination of the total phenolic content from Limonium Brasiliense L. Molecules 18(6):6852-6865. https://doi.org/10. 3390/molecules18066852

31. Pavithra K, Vadivukkarasi S (2015) Evaluation of free radical scavenging activity of various extracts of leaves from Kedrostis foetidissima (Jacq.) Cogn. Food Sci Hum Well 4(1):42-46. https://doi.org/10.1016/j.fshw.2015.02.001

32. Shalaby E, Shanab S (2013) Comparison of DPPH and ABTS assays for determining antioxidant potential of water and methanol extracts of Spirulina platensis. Indian J Mar Sci 42:556-564

33. Lipinski B (2011) Hydroxyl radical and its scavengers in health and disease. Oxid Med Cell Longev. https://doi.org/10.1155/2011/809696

34. Sudha G, Priya MS, Shree RI, Vadivukkarasi S (2011) In vitro free radical scavenging activity of raw pepino fruit (Solanum muricatum aiton). Int J Curr Pharm Res 3(2):4
35. Balouiri M, Sadiki M, Ibnsouda SK (2016) Methods for in vitro evaluating antimicrobial activity: a review. J Pharm Anal 6(2):71-79. https://doi.org/10. 1016/j.jpha.2015.11.005

36. Enzymatic assay of trypsin inhibitor. Sigma-Aldrich. https://www. sigmaaldrich.com/technical-documents/protocols/biology/enzymatic-assayof-trypsin-inhibitor.html. Accessed 5 Sept 2019.

37. Prabhu K, Karar PK, Hemalatha S, Ponnudurai K (2011) A comparative preliminary phytochemical screening on the leaves, stems and the roots of three viburnum Linn. species. Pharm Sin 2(3) https://www.imedpub.com/ abstract/a-comparative-preliminary-phytochemical-screening-on-theleavesrnstems-and-the-roots-of-three-viburnum-linn-species-16520.html

38. Adebayo A, Balade A, Yakubu O (2017) Gas chromatography-mass spectrometry analysis of viburnum opulus $(L)$ extract and its toxicity studies in rats. Asian J Pharm Clin Res 10:383. https://doi.org/10.22159/ajpcr.2017. v10i6.17350

39. Zhang Y-J, Gan R-Y, Li S, Zhou Y, Li A-N, Xu D-P, Li H-B (2015) Antioxidant phytochemicals for the prevention and treatment of chronic diseases. Molecules 20(12):21138-21156. https://doi.org/10.3390/molecules201219753

40. Debnath B, Singh WS, Das M, Goswami S, Singh MK, Maiti D, Manna K (2018) Role of plant alkaloids on human health: a review of biological activities. Mater Today Chem 9:56-72. https://doi.org/10.1016/j.mtchem. 2018.05.001

41. Prabhu K, Karar PK, Hemalatha S, Ponnudurai K (2011) Biological and phytochemical investigations recently carried out on three Viburnum Linn. species-an overview. Int J Pharm Ind Res 1(3):219-241

42. Lobo V, Patil A, Phatak A, Chandra N (2010) Free radicals, antioxidants and functional foods: Impact on human health. Pharmacogn Rev 4(8):118-126. https://doi.org/10.4103/0973-7847.70902

43. Surapneni KM, Chandrasada Gopan VS (2008) Lipid peroxidation and antioxidant status in patients with rheumatoid arthritis. Indian J Clin Biochem 23(1):41-44. https://doi.org/10.1007/s12291-008-0010-x

44. Kasote DM, Katyare SS, Hegde MV, Bae H (2015) Significance of antioxidant potential of plants and its relevance to therapeutic applications. Int J Biol Sci 11(8):982-991. https://doi.org/10.7150/ijbs.12096

45. Gudise V, Chowdhury B, Manjappa AS (2019) In vitro free radical scavenging and antidiabetic activity of aqueous and ethanolic leaf extracts: a comparative evaluation of Argyreia pierreana and Matelea denticulata. Future J Pharm Sci 5(1):13. https://doi.org/10.1186/s43094-019-0014-9

46. Brand-Williams W, Cuvelier ME, Berset C (1995) Use of a free radical method to evaluate antioxidant activity. LWT Food Sci Technol 28(1):25-30. https:// doi.org/10.1016/S0023-6438(95)80008-5

47. Piluzza G, Bullitta S (2011) Correlations between phenolic content and antioxidant properties in twenty-four plant species of traditional ethnoveterinary use in the Mediterranean area. Pharm Biol 49:240-247. https://doi.org/10.3109/13880209.2010.501083

48. Erdogan-Orhan I, Altun ML, Sever-Yilmaz B, Saltan G (2011) Antiacetylcholinesterase and antioxidant assets of the major components (salicin, amentoflavone, and chlorogenic acid) and the extracts of Viburnum opulus and Viburnum lantana and their total phenol and flavonoid contents. J Med Food 14(4):434-440. https://doi.org/10.1089/jmf.2010.0053

49. Prabhu K, Karar PK, Hemalatha S, Ponnudurai K (2011) Isolation of chlorogenic acid from the stems of Viburnum coriaceum Blume. Pharm Sin 2(4) https://www.imedpub.com/abstract/isolation-of-chlorogenic-acid-fromthe-stems-of-viburnum-coriaceum-blume-16978.html

50. Bibi Y, Nisa S, Waheed A, Zia M, Sarwar S, Ahmed S, Chaudhary MF (2010) Evaluation of Viburnum foetens for anticancer and antibacterial potential and phytochemical analysis. Afr J Biotechnol https://doi.org/null

51. Siqueira CF d Q, Cabral DLV, Peixoto Sobrinho TJ d S, de Amorim ELC, de Melo JG, Araújo TA d S, de Albuquerque UP (2011) Levels of tannins and flavonoids in medicinal plants: evaluating bioprospecting strategies. Evid Based Complement Alternat Med. https://doi.org/10.1155/2012/434782 Hindawi

52. Dall'Agnol R, Ferraz A, Bernardi AP, Albring D, Nör C, Sarmento L, Lamb L, Hass M, von Poser G, Schapoval EES (2003) Antimicrobial activity of some Hypericum species. Phytomedicine 10(6-7):511-516. https://doi.org/10.1078/ 094471103322331476

53. Corrales M, Han JH, Tauscher B (2009) Antimicrobial properties of grape seed extracts and their effectiveness after incorporation into pea starch films. Int J Food Sci Technol 44(2):425-433. https://doi.org/10.1111/j.13652621.2008.01790.x 
54. Craik CS, Page MJ, Madison EL (2011) Proteases as therapeutics. Biochem 435(1):1-16. https://doi.org/10.1042/BJ20100965

55. Soualmia F, El Amri C (2018) Serine protease inhibitors to treat inflammation: a patent review (2011-2016). Expert Opin Ther Pat 28(2):93110. https://doi.org/10.1080/13543776.2018.1406478

56. Ketha A, Vedula G, Sastry A (2020) In vitro antioxidant, anti-inflammatory, and anticancer activities of methanolic extract and its metabolites of whole plant Cardiospermum canescens Wall. Future J Pharm Sci 6. https://doi.org/ 10.1186/s43094-020-00028-y

\section{Publisher's Note}

Springer Nature remains neutral with regard to jurisdictional claims in published maps and institutional affiliations.

\section{Submit your manuscript to a SpringerOpen ${ }^{\circ}$ journal and benefit from:}

- Convenient online submission

- Rigorous peer review

- Open access: articles freely available online

- High visibility within the field

- Retaining the copyright to your article

Submit your next manuscript at $\boldsymbol{\nabla}$ springeropen.com 